\title{
Profesionalitas Aparatur Pemerintah Pada Pelayanan Pengukuran Tanah di Kelurahan Wailan Kecamatan Tomohon
}

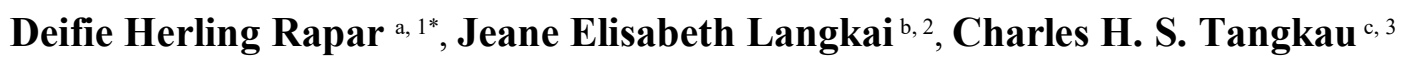

${ }^{a}$ Universitas Negeri Manado, Pascasarjana Ilmu Administrasi Negara, Tondano Indonesia

${ }^{1}$ devirapar@gmail.com*; jeanelangkai@unima.ac.id ; charlestangkau@unima.ac.id

\section{NF O A R T IK E L}

Diterima 00 April 00

Disetujui 00 Oktober 00

Key word:

Professionalism of Government Apparatus

Land Measurement Service

\section{A B S T R A C T}

This study aims to analyze the professionalism of government officials in providing public services related to land measurement and registration for the issuance of certificates in Wailan Village, North Tomohon District. This study uses a qualitative phenomenological approach with the intention of looking at the reality, social phenomena that occur in the community related to land measurement and registration for the issuance of certificates in Wailan Village, North Tomohon District. People who complain about the mechanism of measuring and registering land for the issuance of certificates. The results of the research show that the understanding of village government officials in carrying out the Complete Systematic Land Registration Program in Wailan Village, North Tomohon District, tends to be low, understanding of the certification mechanism such as measurement costs, inspection committee fees land for the purpose of land certification tends to be low, understanding of good public services tends to be low, the measuring letter has not been registered according to statutory provisions.

\section{INTISARI}

\section{Kata kunci: \\ Profesionalitas Aparatur \\ Pemerintah, Pelayanan \\ Pengukuran Tanah, \\ Kota Tomohon}

\begin{abstract}
Penelitian ini bertujuan untuk menganalisis profesionalitas aparatur pemerintah dalam melakukan pelayanan publik terkait pengukuran dan pendaftaran tanah untuk penerbitan sertifikat di Kelurahan Wailan Kecamatan Tomohon Utara. Penelitian ini menggunakan pendekatan kualitatif fenomenologis dengan maksud memandang realitas, fenomena sosial masyarakat yang terjadi terkait pengukuran dan pendaftaran tanah untuk penerbitan sertifikat di Kelurahan Wailan Kecamatan Tomohon Utara. Masyarakat yang mengeluhkan tentang mekanisme pengukuran dan pendaftaran tanah untuk penerbitan sertifikat, Hasil penelitian menunjukan bahwa pemahaman aparatur pemerintah kelurahan dalam menyelenggarakan Program Pendaftaran Tanah Sistematis Lengkap di Kelurahan Wailan Kecamatan Tomohon Utara, cenderung rendah, pemahaman tentang mekanisme sertifikasi seperti biaya ukur, biaya panitia pemeriksa tanah untuk kepentingan sertifikasi tanah cenderung rendah, pemahaman tentang pelayanan public yang baik cenderung rendah, surat ukur belum teregistrasi sesuai ketentuan perundangan.
\end{abstract}




\section{Copyright $@ 2019$ (Deifi Rapar). All Right Reserved}

\section{Pendahuluan}

Badan Pertanahan Nasional melakukan program pelaksanaan pendaftaran tanah dan penerbitan sertifikat untuk tertib administrasi petanahan, dan mebuat Proyek Operasi Nasional Agraria yang diselenggarakan oleh pemerintah kota untuk kepentingan pembuatan sertifikat tanah. Tindak lanjut program tersebut adalah melakukan program Pendaftaran Tanah Sistematis Lengkap, tujuannya untuk memenuhi kebutuhan masyarakat akan legalitas sebuah investasi.

Tim satgas dari BPN yang berpusat di setiap kantor kelurahan atau desa dan secara bersama dengan aparatur kelurahan mendata wilayah yang belum tersertifikasi. Pembiayaan administrasi untuk mekanisme sertifikasi seperti biaya ukur, biaya panitia pemeriksa tanah sampai biaya administrasi pendaftaran dibayarkan dari Anggaran pendapatan Dan belanja Negara, kecuali badan hukum PT, pemilik tanah luas.

Pelayanan publik terkait pengukuran tanah, merupakan tugas/wewenang pemerintah di tingkat Kelurahan/Desa. Untuk itu perlu peningkatan kualitas pelayanan publik secara profesional oleh aparat pemerintah kelurahan. Observasi tugas pokok dan fungsi aparat pemerintah dalam pelayanan publik khususnya pengukuran tanah, di Kelurahan Wailan didapati mekanismenya belum sesuai program Pendaftaran Tanah SistematisLengkap.Reformasi administrasi pemerintahan menghendaki pelayanan public yang jujur, adil, efisien, responsive dan keterbukaan. Sementara dalam melaksanakan pelayanan publik didapati aparat kelurahan belum mampu mengimplementasikan program PRONA dimana terdapat kesalahan didalam pembuatan akta tanah yang merugikan masayarakat. Terdapat sengketa yang berkaitan dengan mekanisme pengukuran, pendaftaran dan pengadministrasian. Lurah tidak mencatat, memelihara daftar induk, peralihan hak atas tanah. Data yang yang teridentifikasi di Kelurahan Wailan Kecamatan Tomohon Utara yakni biaya pengukuran tanah yang tidak pasti, belum adanya Peraturan Daerah yang dijadikan acuan/dasar pengukuran tanah, sumber daya aparat pengukur tanah yang belum kompeten, terjadinya pungutan liar. Berdasarkan latar belakang masalah tersebut maka dilakukan kajian secatra teoritik dan metodik dari aspek profesionalitas aparatur pemerintah Kelurahan dalam melakukan pelayanan publik khususnya pengukuran tanah di Kelurahan Wailan Kecamatan Tomohon Utara.

\section{Metode Penelitian}

Jenis penelitian ini adalah kualitatif fenomenologis. Penelitian ini difokuskan pada profesionalitas aparatur pemerintah dalam mengimplementasikan program Pendaftaran Tanah Sistematis Lengkap di kelurahan Wailan untuk kepentingan sertifikasi. Teknik pengumpulan data adalah : Sumber data adalah:1). observasi mengenai realita atau fenomena yang berkaitan dengan pengukuran dan pendaftaran tanah untuk penerbitan sertifikat di Kelurahan Wailan Kecamatan Tomohon Utara, 2). Dokumen terkait peraturan terkait mekanisme sertifikasi seperti biaya ukur, biaya panitia pemeriksa tanah, 3). Wawancara semi terstruktur terkait profesionalitas aparatur pemerintah pada pelayanan publik terkait pengukuran dan pendaftaran tanah untuk penerbitan sertifikat kepada: a). masyarakat yang mengeluhkan tentang mekanisme pengukuran dan pendaftaran tanah untuk penerbitan sertifikat, b). aparat pemerintah yang melakukan pengukuran dan pendaftaran tanah untuk penerbitan sertifikat, c). sekertaris d). lurah Wailan Kecamatan Tomohon Utara. Dan analisis data yang mengacu pada model Miles dan Huberman.

\section{Hasil dan Pembahasan}

Profesionalitas adalah kemampuan untuk menjalankan tugas pokok dan fungsi dan menyelenggarakan pelayanan publik sesuai ketentuan perundangan yang berlaku. Dalam rangka peningkatan profesionalitas maka perlu dilakukan sosialisasi kepada aparatur kelurahan mengenai tugas okok dan fungsi sebagai pengukur tanah berdasarkan tujuan dan mekanisme program Proyek Operasi Nasional Agraria program Pendaftaran Tanah Sistematis Lengkap. Terkait proses pengukuran tanah, bahwa hasil pengukuran tanah diterbitkan Surat Ukur yang ditandatangani oleh Lurah, Tim Pengukur, dan Para Saksi serta Pemilik Lahan. Kewenangan penerbitan surat ukur adalah kewenangan Lurah. Sedangkan surat pernyataan tertulis tentang penguasaan fisik bidang tanah dimana pemilik lahan melapor kepada Pemerintah Lingkungan, selanjutnya dilanjutkan kepada Lurah. Selanjutnya dilakukan pengecekan informasi mengenai status tanah dalam hal asal usul tanah (tanah warisan) melalui surat Wasiat dan setelah diperoleh informasi bahwa lahan tidak bermasalah, maka pemerintah mengumumkan kepada masyarakat dan selanjutnya dilakukan pengukuran tanah. Surat ukur adalah sah dan dijadikan sebagai landasan penerbitan selanjutnya untuk kepentingan sertfikat.

Sertifikat Hak atas Tanah adalah surat tanda bukti hak sebagaimana dimaksud dalam Pasal 19 ayat (2) huruf c Undang-Undang Nomor

5 Tahun 1960 tentang Peraturan Dasar PokokPokok Agraria untuk Hak atas Tanah, hak pengelolaan, tanah wakaf, yang masing-masing sudah dibukukan dalam buku tanah yang bersangkutan. Kekuatan berlakunya sertifikat sangat penting karena pertama, sertifikat memberikan kepastian hukum pemilik tanah. Kedua, pemberian sertifikat dimaksud untuk mencegah sengketa kepemilikan tanah. Ketiga, dengan kepemilikan sertifikat, pemilik tanah dapat melakukan perbuatan hukum apa saja sepanjang tidak bertentangan dengan undang-undang, ketertiban umum, dan 
kesusilaan, serta mempunyai nilai ekonomi. Pendaftaran tanah adalah rangkaian kegiatan yang dilakukan oleh pemerintah secara terus-menerus, berkesinambungan dan teratur, meliputi pengumpulan, pengolahan, pembukuan dan penyajian serta pemeliharaan data fisik dan data yuridis, dalam bentuk peta dan daftar mengenai bidang-bidang tanah dan satuan-satuan rumah susun, termasuk pemberian sertifikat sebagi surat tanda bukti haknya bagi bidangbidang tanah yang sudah ada haknya dan hak milik atas satuan rumah susun serta hak-hak tertentu yang membebaninya [2].

Pendaftaran tanah diselenggarakan untuk menjamin kepastian hukum, pendaftaran tanah ini diselenggarakan untuk memenuhi kebutuhan masyarakat dan pemerintah. Selanjutnya dalam melaksanakan proses penyelenggaraan tertib hukum pertanahan tersebut dilaksanakan oleh organisasi pelaksana lembaga pemerintahan non departemen yaitu Badan Pertanahan

Nasional/BPN. Badan Pertanahan Nasional (BPN) dibentuk berdasarkan Peraturan Presiden Nomor 20 Tahun 2015 tentang Badan Pertanahan

Nasional. Pembentukan Badan Pertanahan Nasional (BPN) dilatar belakangi oleh adanya kebutuhan, penguasaan dan penggunaan tanah pada umumnya termasuk kepentingan pembangunan yang dirasakan semakin tinggi sehingga dikhawatirkan akan menimbulkan peningkatan permasalahan yang timbul di bidang pertanahan [3]. Kebijakan yang dikeluarkan pemerintah salah satunya dengan mengeluarkan program pensertifikasian tanah secara massal salah satunya adalah Program Pendaftaran Tanah Sistematis Lengkap (PTSL). Program Pendaftaran Tanah Sistematis Lengkap (PTSL) digagas

Pemerintah Republik Indonesia dan dilaksanakan oleh Kantor Kementerian Agraria dan Tata Ruang/Badan Pertanahan Nasional. Berdasarkan Peraturan Menteri Agraria dan Tata Ruang/Kepala

Badan Pertanahan Nasional Republik Indonesia Nomor 12 tahun 2017 tentang Percepatan Pelaksanaan Pendaftaran Tanah Sistematis Lengkap. Dalam Pasal 1 ayat (2) Pendaftaran Tanah Sistematis Lengkap merupakan kegiatan pendaftaran tanah untuk pertama kali yang dilakukan secara serentak bagi semua obyek pendaftaran tanah di seluruh wilayah Republik Indonesia dalam satu wilayah desa/kelurahan atau nama lainnya yang setingkat dengan itu, yang meliputi pengumpulan dan penetapan kebenaran data fisik dan data yuridis mengenai satu atau beberapa obyek pendaftaran tanah untuk keperluan pendaftarannya [4].

Data didalami dan masih terkait surat pernyataan tertulis tentang penguasaan fisik bidang tanah yang menjadi kewenangan Lurah.

Dapat dijelaskan bahwa proses dalam menerbitkan surat tersebut, telah dilakukan secara transparan kepada masyarakat luas melalui pengumuman secara terbuka sebelum pengukuran tanah, dalam jangka waktu 3 (tiga) hari sebelum pengukuran, dan dilakukan pengumuman melalui pengeras suara. Pengumuman tersebut disampaikan agar pihak yang berbatasan langsung dengan lahan yang menjadi objek ukur mengetahui. Data di kembangkan memperkuat data sebelumnya masih terkait proses dalam menerbitkan

Secara normatif bahwa Undang-Undang Pokok Agraria (UUPA) Nomor 5 Tahun 1960 yang berbunyi sebagai berikut.3 (1) Untuk menjamin kepastian hukum oleh pemerintah dilakukan pendaftaran tanah di seluruh wilayah Negara Republik Indonesia menurut ketentuanketentuan yang diatur dengan peraturan pemerintah. (2) Pendaftaran tersebut dalam ayat (1) pasal ini meliputi: a. Pengukuran, pemetaan, dan pembukuan tanah. b. Pendaftaran hak-hak atas tanah dan peralihan hak-hak tersebut. c. Pemberian surat-surat tanda bukti hak, yang berlaku sebagai alat pembuktian yang kuat. (3) Pendaftaran tanah diselenggarakan dengan mengingat keadaan negara dan masyarakat, keperluan lalu lintas sosial ekonomi serta kemungkinan penyelenggaraannya, menurut pertimbangan Menteri Agraria. (4) Dalam peraturan pemerintah diatur biayabiaya yang bersangkutan dengan pendaftaran tersebut ayat (1) di atas, dengan ketentuan bahwa rakyat yang tidak mampu dibebaskan dari pembayaran biaya-biaya tersebut [2]. Apa yang telah diperintahkan oleh Pasal 19 ayat (1) Undang-Undang Pokok Agraria (UUPA) tersebut, kemudian ditegaskan lebih lanjut dalam Pasal 3 Peraturan Pemerintah Republik Indonesia Nomor 24 Tahun 1997 tentang Pendaftaran Tanah, yang tujuannya adalah: (1) Untuk memberikan kepastian hukum dan perlindungan hukum kepada pemegang hak atas suatu bidang tanah, satuan rumah susun, dan hak-hak lain yang terdaftar agar dengan mudah dapat membuktikan dirinya sebagai pemegang hak yang bersangkutan. (2) Untuk menyediakan informasi kepada pihak-pihak yang berkepentingan termasuk pemerintah agar dengan mudah dapat memperoleh data yang diperlukan dalam mengadakan perbuatan hukum mengenai bidangbidang tanah dan satuan-satuan rumah susun yang sudah terdaftar [1].

Terkait Buku Register Tanah diperoleh informasi bahwa sudah hangus terbakar dan yang tersisa hanya surat ukur yang dipegang oleh masyarakat. Untuk buku register saat ini dilampirkan dengan arsip surat ukur. Tapi setelah terjadi pergantian pejabat, mulai adanya perbaikan sehingga buku register tanah kelurahan untuk beberapa tahun terakhir ada tersedia. Tetapi terdapat surat ukur tidak tergistrasi karena adanya oknum pejabat kelurahan yang melakukan pengukuran tanah tanpa berkoordinasi. Sehingga ada surat ukur yang diajukan ke BPN untuk diterbitkan sertifikat tidak tercatat pada buku register. Untuk buku register saat ini dilampirkan dengan arsip surat ukur. Setelah terjadi pergantian pejabat, mulai adanya perbaikan sehingga buku register tanah kelurahan untuk beberapa tahun terakhir ada tersedia tetapi itu butuh waktu dan biaya untuk memenuhinya. 
Terkait biaya penerbitan surat ukur, untuk Lurah dan Pemerintah Kelurahan, sebesar Rp.

750.000,00 ke atas. Untuk masyarakat Kelurahan Wailan dikenakan biaya bervariasi antara $\mathrm{Rp}$. 750.000,00 sampai dengan Rp. 1.000.000,00.

Sedangkan untuk masyarakat luar Kelurahan Wailan dikenakan biaya lebih. Untuk penentuan harga disampaikan oleh Pemerintah Lingkungan ataupun oleh Lurah. Setelah Kepala Lingkungan menyampaikan besaran biaya tersebut kepada pemilik lahan, kemudian diteruskan kepada Lurah untuk disetujui untuk dilanjutkan. Sampai saat ini masyarakat tidak pernah mengajukan keberatan terkait penetapan biaya tersebut. Pernah ada masyarakat yang menanyakan terkait mengapa biaya tersebut terlalu tinggi, maka kami menjelaskan bahwa biaya tersebut menyesuaikan dengan jarak dan kelas tanah. Yang menentukan harga adalah Lurah dan Pemerintah Kelurahan. Jika terjadi perbedaan dalam penentuan harga antara Lurah dan Pemerintah Lingkungan maka Pemilik lahan dapat melakukan penawaran. Seharusnya yang lebih berwenang untuk menentukan harga adalah Pemerintah Lingkungan karena lebih memahami dan mengetahui terkait lahan yang akan diukur. Besaran biaya Rp. 750.000,00 berlaku merata di setiap lingkungan. Kalau di lingkungan yang saya pimpin, untuk biaya tersebut adalah diluar biaya untuk Kepala dan Wakil Kepala Lingkungan. Dan jika sepakat, maka surat akan saya kawal sampai terbit atau ditandatangani. Biaya untuk Kepala dan Wakil Kepala Lingkungan adalah Rp. $100.000,00$ /orang. Biaya tersebut tidak menggunakan kwitansi tanda terima. Tetapi jika ada masyarakat yang meminta kwitansi, maka akan kami siapkan dan akan ditandatangani oleh lurah. Tetapi selama ini kami tidak pernah membuat kwitansi tanda terima. Untuk biaya Rp. 350.000,00 sesuai dengan yang diatur dalam Peraturan Walikota adalah biaya untuk penerbitan Sertifikat Tanah di BPN. Dari biaya tersebut kami selaku Kepala dan Wakil

$$
\text { Kepala Lingkungan menerima Rp. }
$$

25.000,00/orang untuk biaya transport ke Kantor BPN. Adanya tanggapan terkait perda yang mengatur biaya pengukuran untuk PTSL di kota Tomohon yang ditetapkan Rp.350.000 dikatakan tidak mencukupi, namun tidak mencukupi apa tidak dijelaskan informan, artinya standar penetapan oleh pemerintah Kota Tomohon mendapat resistensi dari pihak Kelurahan dan Lingkungan. Dari data menyebutkan bahwa Untuk biaya surat ukur dikenakan sebesar Rp. 1.000.000,00. Bervariasi untuk masyarakat Kelurahan Wailan, tapi untuk Masyarakat luar

$$
\begin{array}{cc}
\text { Kelurahan } & \text { Wialan } \\
\text { biaya } & \text { Rp. }
\end{array}
$$

1.500.000,00. Hal ini sesuai dengan keputusan Rapat Perangkat Kelurahan. Kami tim ukur hanya mendengar dari lurah termasuk biaya. Jadi tim pengukur hanya melaksanakan instruksi dari lurah. Untuk biaya penerbitan surat ukur dikenakan sebesar Rp.
1.000.000,00. Bervariasi untuk masyarakat Kelurahan Wailan, tapi untuk Masyarakat luar Kelurahan Wialan dikenakan biaya Rp. 1.500.000,00 atau lebih. Hal ini nyata bahwa adanya ketidaktaatan terhadap aturan berlaku dalam hal ini Peraturan Walikota Tomohon No. 44 Tahun 2017. Dalam peraturan program pendaftaran tanah sistematis lengkap (PTSL) yang telah dibiayai oleh pemerintah, berdasarkan Daftar Isian Anggaran (DIPA) Tahun 2019 mendapatkan alokasi dana dalam program PTSL. Pemerintah telah mengupayakan dengan keras dalam hal untuk memberikan sertipikat hak atas tanah dengan program ini masyarakat seharusnya dibebaskan dari biaya apapun dengan itu diharapkan dapat menyadarkan terhadap pandangan masyarakat bahwa pentingnya pendaftaran tanah dan sebuah sertfikat hak atas tanah yang dimilikinya untuk kehidupan mereka, dan pemerintah pun dapat dengan mudah menertibkan administrasi, tertib pemeliharaan tanah dalam bidang pertanahan dalam Catur Tertib Pertanahan, namun kenyataannya tidaklah sesuai harapan masyarakat. Pendaftaran Tanah Sistematis Lengkap (PTSL) adalah kegiatan pendaftaran tanah untuk pertama kali yang dilakukan secara serentak bagi semua obyek pendaftaran tanah di seluruh wilayah Republik Indonesia dalam satu wilayah desa/kelurahan atau nama lainnya yang setingkat itu, yang meliputi pengumpulan dan penetapan kebenaran data fisik dan data yuridis mengenai satu atau beberapa obyek pendaftaran tanah untuk keperluan pendaftarannya. Pada dasarnya kebijakan Pendaftaran Tanah Sistematis Lengkap ini dibuat karena rasa keprihatinan Presiden Joko Widodo terhadap beberapa kasus soal sengketa tanah yang terjadi di Masyarakat [5].

$$
\text { Selanjutnya untuk mengetahui }
$$

Profesionalitas ASN Dalam Menyelenggarakan Program Pendaftaran Tanah Sistematis Lengkap (PTSL) Di Kelurahan Wailan Kecamatan Tomohon Utara, indikator pertama yang akan dilihat adalah "Prosedur". Kewenangan Pemerintah Kelurahan yaitu untuk menerbitkan surat ukur dan menjadi dasar BPN menerbitkan setifikat tanah. Bervariasinya biaya ukur ini disebabkan oleh kurangnya sosialisasi dan diakibatkan karena kelurahan harus mengejar target untuk penerbitan sertifikat tanah. Sehingga sebagian besar surat ukur yang akan diterbitkan sertifikat belum ditandatangani oleh Lurah karena terkendala pembiayaan. Untuk pelaksanaan tahapan tersebut mengacu pada keputusan kelurahan yang tidak tertulis. Termasuk penentuan besaran biaya pengukuran. Jadi untuk biaya bervariasi. Hal ini karena kurangnya sosialisasi dan diakibatkan karena kelurahan harus mengejar target untuk penerbitan sertifikat tanah. Sehingga sebagian besar surat ukur yang akan diterbitkan sertifikat belum ditandatangani oleh Lurah karena terkendala pembiayaan.

Kurangnya pemahaman aparat pemerintah kelurahan terkait prosedur dan landasan aturan yang mengikat program ini membuat terjadinya beberapa kesalahan prosedur pada pungutan biaya pengukuran 
tanah, hal ini dibenarkan oleh informan "YA", demikian hasil wawancara:

"Kalau tidak salah, ada aturan dari 3 menteri yang mengatur tentang besaran biaya pengukuran tanah sebesar Rp. 350.000,00. Tapi biaya tersebut hanya untuk penerbitan sertifikat. Untuk Penerbitan surat ukur oleh Kelurahan hanya didasari oleh kesepakatan bersama Perangkat Kelurahan melalui Rapat Perangkat. (Wawancara September 2019).

Terkait adanya ada aturan dari 3 menteri yang mengatur tentang besaran biaya pengukuran tanah sebesar Rp. 350.000,00. Tapi biaya tersebut hanya untuk penerbitan sertifikat belum sepenuhnya dipahami oleh informan sebagai implementor. Malah terdapat temuan baru untuk Penerbitan surat ukur oleh Kelurahan hanya didasari oleh kesepakatan bersama Perangkat Kelurahan melalui Rapat Perangkat, hal ini tidak sesuai dengan Peraturan Walikota Tomohon No. 44 Tahun 2017. Rendahnya pemahaman aparat pemerintah kelurahan terkait prosedur dan landasan aturan yang mengikat program ini membuat terjadinya beberapa kesalahan prosedur pada pungutan biaya pengukuran tanah. Informan dengan jujur mengemukakan ketidakpahaman terhadap aturan dan prosedur. Pemerintah kelurahan sebagai pelaksana mitra dengan BPN tidak memahami prosedur terkait Objek, Subjek, Alas Hak, dan Proses serta Pembiayaan Kegiatan pada program Pendaftaran Tanah Sistematis Lengkap (PTSL) Di Kelurahan Wailan

\section{Kecamatan Tomohon Utara [5].}

Prosedur pada program Pendaftaran Tanah Sistematis Lengkap (PTSL) Di Kelurahan Wailan Kecamatan Tomohon Utara belum dipahami dengan baik. Pendaftaran Tanah Sistematis Lengkap (PTSL) dalam rangka percepatan pensertipikatan hak atas tanah di Kota Tomohon cukup penting dilaksanakan untuk dapat menimbulkan kepastian hukum bagi masyarakat yang menguasai bidang tanahnya, sehingga penguasaan bidang tanah oleh masyarakat di wilayah Kota Tomohon memiliki dasar hukum yang jelas, sehingga menimbulkan tertib hukum hak kepemilikan atas tanah oleh masyarakat di wilayah tersebut. Apabila pendaftaran sistematis lengkap dalam rangka percepatan pensertipikatan hak atas tanah di Kota Tomohon tersebut tidak segera dilaksanakan maka akan menimbulkan suatu ketidakpastian hukum terhadap status hak atas tanah yang ada di masyarakat, sehingga dapat menimbulkan suatu sengketa atau konflik antar sesama anggota masyarakat yang menimbulkan kekacauan dalam kehidupan masyarakat tersebut. Namun yang menjadi permasalahan adalah ketika tahapan awal di kelurahan yang masih menuai masalah pelayanan yang kurang maksimal dan tgransparansi biaya yang kurang oleh pemangku kepentingan.

Peraturan Menteri Agraria dan Tata Ruang/Kepala Badan Pertanahan Nasional Republik Nomor 1 Tahun 2017 tentang
Percepatan Pendaftaran Tanah Sistematis Lengkap terlihat jelas bahwa adanya penerapan dari asas tersebut. Secara tertulis dimuat didalam Pasal 2 ayat (2) yang pada intinya mengatakan bahwa adanya program dari pemerintah ini yang berupa Pendaftaran Tanah Sistematik Lengkap yang dilaksanakan untuk memberikan jaminan kepastian hukum dan perlindungan hukum hak atas tanah kepada masyarakat secara pasti yang berupa pemberian sertifikat, dengan prosesnya yang sederhana cepat lancar, aman, adil, merata dan terbuka untuk siapapun tanpa terkecuali dengan memenuhi syarat-syarat yang telah ditentukan dalam peratura perundangundangan serta akuntabel yang mana adanya pertanggung jawaban dari penyelenggara program ini [6].

Tujuan Pendaftaran Tanah Sistematis Lengkap (PTSL) adalah untuk percepatan pemberian kepastian hukum dan perlindungan hukum Hak atas Tanah masyarakat secara pasti, sederhana, cepat, lancar, aman, adil, merata dan terbuka serta akuntabel, sehingga dapat meningkatkan kesejahteraan dan kemakmuran masyarakat dan ekonomi negara, serta mencegah sengketa dan konflik pertanahan. Sasaran Pendaftaran Tanah Sistematis Lengkap (PTSL) merupakan seluruh obyek pendaftaran tanah di seluruh wilayah Republik Indonesia. Meliputi seluruh bidang tanah tanpa terkecuali, baik bidang tanah yang belum ada hak atas tanahnya maupun bidang tanah hak, yang belum terdaftar dalam suatu wilayah desa atau kelurahan.

\section{Ucapan Terimakasih}

Terima kasih kepada: Pemerintah Kota Tomohon khususnya pemerintah Kelurahan Wailan Kecamatan Tomohon Utara atas kesediaannya dalam berpartisipasi demi lengkapnya karya ilmiah ini.

\section{Kesimpulan}

Penelitian ini berkesimpulan bahwa: (1) Buku register tanah sudah hangus terbakar, untuk register dibawah tahun 2000, dan terdapat beberapa surat ukur tidak tergistrasi karena adanya oknum pejabat kelurahan yang melakukan pengukuran tanah tanpa berkoordinasi, terdapat surat ukur yang diajukan ke BPN tidak tercatat pada buku register. (2). Biaya untuk pengukuran, belum ada patokan dasar yang pasti. (3). Rendahnya profesionalitasnya pemerintah Kelurahan dalam menyelenggarakan Program Pendaftaran Tanah Sistematis Lengkap (PTSL) Di Kelurahan Wailan Kecamatan Tomohon Utara. (4) Penetapan jumlah biaya pengukuran tanah ditetapkan sepihak berdasarkan pada rapat pemerintah kelurahan. (5) Prosedur program Pendaftaran Tanah Sistematis Lengkap (PTSL) Di Kelurahan Wailan Kecamatan Tomohon Utara belum dipahami dengan benar. 6). Peraturan yang menyangkut 
program PTSL belum disosialisasikan secara efektif kepada apaat kelurahan dan masyarakat.

\section{Referensi}

[1] Peraturan Kepala Badan Pertanahan Nasional Nomor 3 Tahun 1997 tentang Ketentuan Pelaksanaan Peraturan Pemerintah Nomor 24 Tahun 1997 Tentang Pendaftaran Tanah.
[2] Undang-undang Nomor 5 Tahun 1960 Tentang Peraturan Dasar Pokok Agraria

[3] Peraturan Presiden Nomor 20 Tahun 2015 tentang Badan Pertanahan Nasional Peraturan Peraturan Menteri Agraria dan Tata Ruang/Kepala Badan Pertanahan Nasional Republik Indonesia Nomor 12 tahun 2017

[4] Peraturan Walikota Tomohon No. 44 Tahun 2017

[5] Peraturan Menteri Agraria dan Tata Ruang/Kepala Badan Pertanahan Nasional 